\title{
ANDRADE, Carlos Drummond de. Carlos e Mário: correspondência entre Carlos Drummond de Andrade e Mário de Andrade: 1924-1945. Rio de Janeiro: Bem-te-Vi, 2002.
}

Márcia Michelin Laboissière Universidade Federal de Minas Gerais

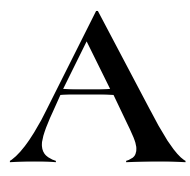

leitura de cartas pessoais implica sempre alguma revelação. São muitas as coisas que as cartas dão a conhecer e muitas explicações ali se apresentam para justificar peculiaridades do comportamento, inclinações e hábitos de vida. Como manifestação de um gesto singular, as cartas falam da construção da subjetividade que se dá no encontro com o outro. Há ainda cartas, como as que compõem grande parte da imensa correspondência de Mário de Andrade, cartas de escritores, cujo fascínio encontra-se também na trilha dos caminhos percorridos no ato da criação artística. As cartas trocadas entre Mário de Andrade e Carlos
Drummond de Andrade ao longo de mais de vinte anos de amizade são dessas que contemplam os leitores com finos pormenores da arte de fazer versos e da aplicação de teorias da versificação.

Desde 1982, quando Drummond publicara as cartas de Mário a ele dirigidas sob o título de A lição do amigo, dispúnhamos de documentos do processo criativo drummoniano dados pela disposição investigativa de Mário. No sentido da elucidação da produção artística, assim como em outros aspectos, a interação epistolar entre Mário e Drummond, vem a ser complementada por publicação recente das cartas de Drummond. Entre cartas, bilhetes e cartões, a 
densa edição soma cento e sessenta e um documentos acrescidos de mais de trezentas fontes icono-gráficas, de prefácio e comentários de Silviano Santiago e das notas de autoria de Drummond da edição de 1982.

A ampla correspondência Carlos/Mário, que, sobretudo nos primeiros anos, toma o sentido já aludido de uma lição, é provocada por Drummond, em 1924, após o primeiro contato em Belo Horizonte entre os jovens mineiros e a caravana paulista com ares modernistas de interesse na tradição histórica mineira.

Transpostos os acertos de contas com as influências passadistas de Anatole France, esclarecido o sentido do nacionalismo nas intenções modernistas e dada a experiência do mestre para observação do discípulo na resposta inicial de Mário, segue a correspondência, já na segunda carta de Drummond, acompanhada de versos que requerem apreciação crítica. E sendo a orientação de jovens poetas uma tarefa da qual nunca se eximira Mário de Andrade, inicia-se então o esquadrinhamento do processo criativo de Drummond. Cartas anteriores a 1930, colocam em questão a fatura dos poemas de Alguma poesia, que viria a ser o primeiro livro de Drummond, e, esmiuçando composições em seus estados provisórios, sugerem acréscimos, cortes e substituições. São exortações de alta consciência estética visando aprimoramento estilístico e técnico com a marca da novidade e do experimentalismo ao gosto modernista. A intensidade do lirismo, a interferência negativa da prosa, os meneios de sintaxe, a repetição de palavras, julgada perigosa e decadente, a busca da expressividade que mede o emprego de pronomes, artigos e pontuação são tópicos das lições das cartas de Mário que orientam um novo uso da linguagem.

Concedendo destaque para o que se constitui como conteúdo ensaístico dessa correspondência, observa-se a clara conformação do papel de leitor crítico assumido por Mário de Andrade frente a Drummond. Desse modo, as cartas servem como instrumento de compreensão da obra artística, podendo ser lidas na relação intertextual que estabelecem com esta.

Mas essas cartas revelam também a construção de um histórico do procedimento de uma leitura empírica. Ou seja, Mário, além de comportar-se como o leitor ideal, disposto a participar do jogo do texto e a fazer apontamentos dessa leitura, é também o leitor real envolvido pela simpatia e orientado pelos valores que lhe são caros. 
No transcurso dessa correspondência, na sua extensão de mais de vinte anos, a reconfiguração desses valores implica mudanças na disposição estética de Mário. Como documentos de ampla significação, as próprias cartas trazem também indícios de reorientações éticas ou políticas que plasmam valores e redimensionam a recepção estética dos textos lidos. Assim, na mescla de fragmentos de acontecimentos de ordem diversa que compõe a escrita epistolar, encontra-se justificativa tanto para o silêncio de Mário no tocante a Brejo das almas, segundo livro de Drummond, editado em 1934, como a ampla aprovação do terceiro livro, Sentimento do mundo, em carta de 1942.

Naquele momento - meados da década de trinta -, pelo que pode se conhecer por outras fontes e pelas informações que a própria correspondência Carlos/Mário vem complementar, observa-se Mário aprofundar seu conceito de arte social e assumir atitudes a partir de uma revisão pessoal do papel político do intelectual. Por certo, a radicalização do antiindividualismo de Mário é o corolário de sua nova propensão para a vida prática. E é provável que esse antiindividualismo sustente a frieza da recepção da segunda safra dos poemas de Drummond, visto que o livro traz composições que exacerbam o tema do "eu".

Contraposta ao silêncio da recepção de Brejo das almas, encontra-se a veemente expansão do leitor empírico que pode ser observada no registro da leitura de Sentimento do mundo em carta de 1942. Segundo Mário, o livro vem ao encontro de uma grande necessidade do momento e, justo por isso, provoca intensa comoção: "Estava extasiado. E extasiado no que eu desejava me extasiar, na única coisa que poderia, em arte, me extasiar por estes tempos, extasiado em humanidade, no, enfim, no sentimento do mundo.". Mário já não censura a "exasperação egocêntrica de Drummond", como o fez na crítica dos primeiros poemas. Reconhece a presença do "eu", mas parece concluir que o fato de Drummond não conseguir transcender a si mesmo só pode trazer benefícios para o estado lírico dos poemas.

Numa inversão dos pólos, a leitura das cartas revela Drummond leitor de Mário. No entanto, fica também demonstrado que as investidas críticas de Drummond reconstituem os modelos do mestre, quando não são abortadas, de início, pela inconveniência das formas cerimoniosas. Isso significa que Mário não pôde encontrar na relação epistolar com Drummond a 
condição auto-reflexiva e de troca mútua que lhe proporcionou a correspondência com Bandeira. Para observar Drummond expandindo-se um pouco mais em crítica e em reflexão poética, é preciso ler, por exemplo, suas cartas trocadas com João Cabral de Melo Neto que estão em edição recente organizada por Flora Süssekind.

Se as cartas de Drummond são fracos documentos de conformação do leitor contrastadas com a profusão das anotações de leitura de Mário, no tocante ao surgimento da obra drummoniana, podem ser bastante reveladoras. Nesse outro aspecto essa correspondência pode ser vista também como a condição de possibilidade que faz surgir uma obra. Na ordem da escrita, Drummond encontra em Mário a destinação da sua obra poética, e quanto menos se expande nas cartas, mais se realiza nos versos.

Ampliando as possibilidades de leitura da correspondência Carlos/Mário, outros aspectos podem ser revelados. Porém, é quase certo encontrar mais do que um sentido puramente estético implicado nas temáticas a serem inventariadas tomando por base os extensos desdobramentos reflexivos que trazem as cartas - visto que, para Mário, como para a intelectualidade modernista de um modo geral, o sentido da forma estética é sempre complementado pela busca de um modo mais verdadeiro e justo de estar presente no mundo, e o próprio gesto epistolar torna-se exemplo de uma atitude expressiva da tentativa de conciliar ética e expressão estética. Assim, para os que desejam compactuar da violação dessa correspondência é preciso fazer lembrar que, se em casos não notáveis, a correspondência privada pode abrir-se para múltiplas revelações, nesse caso em especial, que conta com missivistas ilustres para quem vida e literatura confluem, a experiência da leitura poderá tornarse tarefa de aventura. 